\title{
MEMBANGUN TEORI POLITIK HUKUM ISLAM DI INDONESIA
}

\author{
Abdul Halim \\ Fakultas Syariah dan Hukum UIN Syarif Hidayatullah Jakarta \\ Jl. Ir. H. Juanda 95, Ciputat, Jakarta, 15412 \\ E-mail: ahalimforasahan2010@yahoo.com
}

\begin{abstract}
Constructing a Political Theory af Islamic Law in Indonesia. This study confirms that the transformation of Islamic law into national law has no correlation with the struggle towards an Islamic country or Islam as the foundation of the state. Islamic law legislation are regulations that have a positive contribution to strengthening the commitment of Muslims towards the Indonesian nation-state. This study refutes the notion that the accommodation of Islamic law within legislation is an agenda aiming towards an Islamic state. The process of accommodation of Islamic law does not need to be feared, because the process is supported by the power of cultural Islam. Besides, Islamic law is at the legal source level so that the accommodation into pre-legislation undergoesstringent testing in order to always be in accordance with Pancasila and the 1945 Constitution.
\end{abstract}

Keywords: politic law, legislation, Islamic law, constitutional theory and the theory of accommodation

Abstrak: Membangun Teori Politik Hukum Islam di Indonesia. Studi ini menegaskan bahwa transformasi hukum Islam ke dalam hukum nasional tidak memiliki hubungan dengan perjuangan menuju negara Islam atau Islam sebagai dasar negara. Legislasi hukum Islam menjadi perundang-undangan memiliki kontribusi positif dalam memperkuat komitmen umat Islam terhadap negara kebangsaan Indonesia. Studi ini membantah pendapat yang menyatakan bahwa akomodasi hukum Islam oleh peraturan perundang-undangan merupakan agenda menuju negara Islam. Proses akomodasi hukum Islam tidak perlu dikhawatirkan karena proses itu didorong oleh kekuatan Islam kultural. Selain itu, hukum Islam berada pada tataran sumber hukum sehingga akomodasinya ke dalam perundang-undangan terlebih dahulu mengalami pengujian yang ketat agar selalu sesuai dengan Pancasila dan UUD 1945.

Kata Kunci: politik hukum, legislasi, hukum islam, teori konstitusi dan teori akomodasi

\section{Pendahuluan}

Perdebatan seputar penerapan syariah dalam negara merupakan salah satu objek studi yang tidak pernah kehilangan daya tarik dan tetap aktual. Perdebatan itu telah berlangsung sejak periode awal sejarah pelembagaan hukum Islam, yakni masa pemerintahan khalifah kedua Daulah Abbasiyah, Abû Ja'far al-Mansûr (137 H/754 M-158 H/775 M) ${ }^{1}$ dan Khalifah Hârûn

Naskah diterima: 12 Maret 2013, direvisi: 3 Juni 2013, disetujui untuk terbit: 14 Juni 2013.

${ }^{1}$ Khalifah Abû Ja'far al-Mansûr meminta kesediaan Imâm Mâlik (94 H/716 M-179 H/795 M) untuk menjadikan kitab al-Muwatta' sebagai pedoman hukum negara, bahkan jika perlu melalui paksaan. Imâm Mâlik menolak usul khalifah al-Mansûr atas pertimbangan bahwa di masing-masing wilayah memiliki mazhab pemikiran sendiri dan masyarakat semestinya diberikan kebebasan melaksanakan hukum sesuai dengan pemahaman masyarakat. Penolakan Imâm Mâlik kelihatannya bukan karena tidak menghendaki setiap orang untuk mengikuti tradisi masyarakat Madinah, tetapi lebih disebabkan karena tradisi Madinah bukan sesuatu yang dapat dipaksakan melalui sebuah kekuatan perintah resmi negara. Yasin Dutton, Asal Mula Hukum Islam Alquran, Muwatta',
al-Rashîd (170 H/786-193 H/ 809 M). ${ }^{2}$ Intervensi negara dalam kebijakan agama juga terjadi pada abad XIX, dimana Kekaisaran Turki Uthmani menetapkan hukum Barat sebagai hukum nasional yang berakibat terjadinya dikotomi antara hukum sekular (umum) dan hukum syariah. ${ }^{3}$ Pada $1876 \mathrm{M}$ masyarakat Turki menjadikan kitab Undang-undang al-Majallâh al-

dan Praktik Madinah, (Yogyakarta: Islamika, 2003), h. 56-57.

${ }^{2}$ Imâm Mâlik mengubah pendiriannya dan kemudian mengabulkan permintaan khalifah Hârûn al-Rashîd karena khalifah dianggap dapat bertindak lebih bijaksana dan terjaga dari tindakan kesewenangwenangan. Kemudian atas dukungan penguasa, kitab al-Muwatta karya Imâm Mâlik dijadikan sebagai pedoman resmi negara dalam menyelesaikan persoalan hukum di tengah-tengah masyarakat dan mazhab Maliki menjadi mazhab yang paling berpengaruh karena mendapat dukungan negara, sekaligus mazhab resmi negara. Muhammad Baltajî, Minhâj al-Tashrî̀ al-Islâmî, (Riyâd: t.p., 1977), h. 79. Lihat juga Joseph Schacht, An Introduction to Islamic Law, (London: Oxford University Press, 1964), h. 55-56.

3 Mohammad Atho Mudzhar, Fatwa-Fatwa Majelis Ulama Indonesia: Sebuah Studi Tentang Pemikiran Hukum Islam di Indonesia, 1975 - 1988, (edisi dwibahasa), (Jakarta: INIS, 1993), h. 3. 


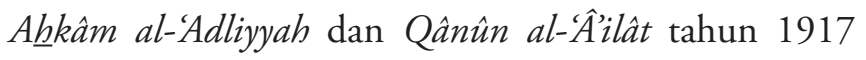
$M$ yang kemudian disebarluaskan ke seluruh wilayah Turki Uthmani sebagai rujukan resmi negara yang berorientasi pada mazhab $\underline{\text { Hanafi. }}{ }^{4}$

Kebijakan negara menjadikan syariah sebagai hukum negara semakin intens dilakukan awal abad XX, ketika terjadi proses pembentukan negara-negara di dunia Islam, bersamaan dengan berakhirnya dominasi kolonialisme Barat di negara-negara Muslim seperti Turki, Mesir, Sudan, Maroko, Pakistan, Malaysia, dan Aljazair. Negaranegara Muslim ini mengalami kesulitan mengembangkan hubungan yang memungkinkan (viable) antara syariah dan negara. Perdebatan terhadap syariah bukan hanya di negara mayoritas Muslim, tetapi merambah ke negaranegara sekuler. ${ }^{5}$ Terlebih lagi, migrasi masyarakat Muslim telah membawa perdebatan ini ke Benua Eropa, Amerika Utara, dan Amerika Selatan. ${ }^{6}$

Tidak terkecuali negara Indonesia modern, ditinjau dari perspektif religio-politis, syariat Islam dan negara adalah dua entitas yang sepanjang sejarah Indonesia senantiasa terlibat pergumulan dan ketegangan abadi dalam memosisikan relasi agama (syariat Islam) dan negara, antara proyek sekularisasi dan Islamisasi negara dan masyarakat. Ketegangan ini terjadi dalam dua tataran penting yang berbeda. Pertama, tataran scholastik atau bersifat teoritik-idealistik. Perdebatan ini mencuat ke permukaan pada akhir tahun 1930-an antara Sukarno dan Mohammad Natsir. ${ }^{7}$ Kedua, tataran realisticpolitik atau ideologis-empirik. Polemik ini terjadi ketika merumuskan dasar konstitusi negara Indonesia modern pasca-kolonial yang berlangsung dalam sidang-sidang Badan Penyelidik Usaha-usaha Kemerdekaan Indonesia (BPUPKI), 28 Mei-1 Juni 1945 dan 10-17 Juli 1945, dan dalam sidang-sidang Panitia Persiapan Kemerdekaan Indonesia (PPKI) 18 sampai 22 Agustus 1945, dalam rangka penyusunan dan pengesahan UUD 1945.

Perdebatan dalam ranah ideologis tersebut berimplikasi pada perdebatan ranah hukum. Konflik

${ }^{4}$ Tahir Mahmood, Family Law Reform in the Muslim World, (New Delhi: The India Law Institute, 1972), h. 17. Lihat M. Atho' Mudzhar dan Khairuddin, Hukum Keluarga di Dunia Islam Modern Studi Perbandingan dan Keberanjakan UU Modern dari Kitab-kitab Fikih, (Jakarta: Ciputat Press, 2003), h. 12.

${ }^{5}$ Lihat Muhammad Tahir Azhary, Negara Hukum Suatu Studi tentang Prinsip-prinsipnya Dilihat dari Segi Hukum Islam, Implementasinya pada Periode Negara Madinah dan Masa Kini, (Jakarta: Kencana, 2004), h.19-20.

${ }^{6}$ Muhammad Khalid Mas'ud, "Pencarian Landasan Normatif Syariah Para Ahli Hukum Islam" dalam Dinamika Kontemporer Dalam Masyarakat Islam, dihimpun oleh Dick van der Meij, diterjemahkan oleh Soemardi, (Jakarta: INIS, 2003), h. 3.

7 Deliar Noer, Gerakan Modern Islam di Indonesia 1900-1942, cet. VIII, (Jakarta: LP3ES, 1996), h. 296-297. dan pergumulan dalam ranah ini terjadi sebagai konsekuensi dari: Pertama, dilihat dari segi pluralitas jenis penduduknya, masyarakat Indonesia mempunyai sistem hukum yang berlaku sejak zaman primitif dari kebiasaan atau adat istiadat sampai dengan ketentuan yang diyakini bersama untuk dipatuhi. Kebiasaan atau adat istiadat ini dapat disebut hukum adat, hukum kebiasaan (customary law) atau hukum yang hidup di tengahtengah masyarakat (the living law). Kedua, dari segi agama terdapat nilai-nilai agama yang diyakini bersama, dijadikan sistem kehidupan yang dianggap sebagai hukum yang bersumber dari agama yang diyakini sebagian besar masyarakat. Ketiga, sebagai negara yang pernah dijajah selama 350 tahun maka kolonial Belanda jelas membawa sistem hukum Belanda ke Indonesia dan bahkan memaksakan hukumnya kepada masyarakat jajahannya. ${ }^{8}$ Ketiga faktor ini melahirkan tiga sistem atau mazhab hukum di Indonesia, yaitu hukum adat, hukum Islam ${ }^{9}$ dan hukum Barat (sipil). Karena itu beralasan penilaian Daniel S. Lev yang menyatakan bahwa sistem hukum Indonesia merupakan satu dari sekian banyak sistem hukum yang lebih rumit di dunia. ${ }^{10}$

Selain problem politis dalam transformasi nilai-nilai Islam ke dalam perundang-undangan negara, kerumitan yang sama juga ditemui dalam intern umat Islam karena pemaknaan terhadap syariah itu sendiri memiliki problem tersendiri pula, di mana mazhab pemikiran dan sistem hukum Islam tidak tunggal. Varian dan corak pemikiran dalam menyikapi hubungan syariah dan negara melahirkan tiga persimpangan jalan. ${ }^{11}$ Pertama, satu jalan menuju pemberlakuan hukum Islam berasal dari kelompok yang menghendaki hukum Islam dapat berlaku di Indonesia untuk mengatur pemeluknya. ${ }^{12}$ Kedua, satu jalan dari kelompok yang menginginkan adanya kesatuan dan keseragaman hukum. Agama hanya sebagai bahan baku dalam pembentukan hukum nasional. ${ }^{13}$ Paradigma berpikir kelompok ini adalah men-

${ }^{8}$ A. Qodri Azizy, Hukum Nasional: Eklektisisme Hukum Islam \& Hukum Umum, (Jakarta: Teraju, 2004), h. 138-139.

9 Subekti, Law in Indonesia, (Jakarta: Yayasan Proklamasi Center for Strategic and International Studies, 1982), h.6.

${ }^{10}$ Daniel S. Lev, Peradilan Agama Islam di Indonesia Suatu Studi Tentang Landasan Politik Lembaga-lembaga Hukum, Alih bahasa oleh Zaini Ahmad Noeh, (Jakarta: Intermasa, 1986), h. 24.

11 Satria Effendi M. Zein, "Ijtihad Sepanjang Sejarah Hukum Islam: Memposisikan K.H. Ali Yafie,” dalam Jamal D. Rahman (Ed.), Wacana Baru Fiqih Sosial 70 Tahun K.H. Ali Yafie, (Bandung: Mizan, 1997), h. 153-156.

12 Munawir Sjadzali, Islam dan Tata Negara: Ajaran, Sejarah dan Pemikiran, (Jakarta: UI Press, 1993), h.1. Lihat juga M. Din Syamsuddin, Islam dan Politik Era Orde Baru, (Jakarta: Logos, 2001), h. x.

${ }^{13}$ Busthanul Arifin "Lâ Yanfa' Takallum bi Haqq lâ Nafâdha lah", 
jaga hubungan yang seimbang antara syariat dan negara. Pada kondisi tertentu dilakukan formalisasi hukum Islam dalam perundang-undangan negara, pada saat yang lain Islam sebagai sumber etika-moral. Perspektif ini disebut moderat-konstitusional. Ketiga, simpang jalan lainnya adalah kelompok yang tidak menginginkan berlakunya hukum Islam secara terlembaga dan bahkan ada kecenderungan menyingkirkan hukum Islam. ${ }^{14} \mathrm{Kubu}$ pendukung paham ini diwakili sebagian besar nonmuslim dan sebagian kecil umat Islam beraliran nasionalis sekuler. Perspektif ini disebut liberal-sekularistik.

Menurut J.N.D. Anderson tiga sikap itu menjadi ciri umum dunia Islam dalam penerapan syariah. Tiga sikap dunia Islam ini sejalan dengan sikap masyarakat Indonesia dalam menyikapi syariah dalam negara. Sikap ini jelas tidak terhindar dari polemik dan kepentingan politik dalam menentukan posisi syariah dalam negara. Bahkan jika dilihat dari teori sosial khususnya critical theory, polemik itu tidak bisa dilepaskan dari kepentingan politik penguasa, masyarakat, dan elite politik. Karena itu, sebenarnya dibalik pemikiran apapun, pada hakekatnya implisit atau eksplisit mempunyai kandungan dan implikasi politik. ${ }^{15}$ Perbedaan paradigma pemikiran itu terlihat jelas ketika terjadi interaksi antara pusat-pusat kekuasaan (power points) baik di tingkat inpra-struktur maupun supra-struktur di tengah-tengah masyarakat seperti partai politik, pemerintah, ABRI, ormas keagamaan/ lembaga swadaya masyarakat, masyarakat muslim dan non-muslim serta media massa dalam proses legislasi hukum Islam di Indonesia. Pada masa pemerintahan Presiden Soeharto misalnya beberapa produk hukum seperti UU No. 1 Tahun 1974 tentang Perkawinan dan UU No. 7 Tahun 1989 tentang Peradilan Agama merupakan contoh terbaik untuk melihat bagaimana pola-pola interaksi dan dinamika konflik dan akomodasi yang muncul pada masa Orde Baru, dan mengundang perdebatan yang cukup sengit. Perdebatan-perdebatan itu bahkan dikaitkaitkan dengan persoalan hak asasi manusia, isu negara Islam, dan Piagam Jakarta.

Makalah pada Sarasehan Sehari IAIN Syarif Hidayatullah, Jakarta, 10 Pebruari 2000, h. 2. Lihat juga Busthanul Arifin,"Menghidupkan Kembali Norma-Norma Hukum Islam," Makalah pada seminar di Padang pada tanggal 27 Desember 2002, h.2.

${ }^{14}$ Satria Effendi M. Zein, "Munawir Sjadzali dan Reaktualisasi Hukum Islam di Indonesia," dalam Muhammad Wahyu Nafis (Ed.), Kontekstualisasi Ajaran Islam 70 Tahun Prof, Dr. H. Munawir Sjadzali, M.A., (Jakarta: Paramadina, 1995), h. 288-289.

15 Jurgen Habermas, Knowledge and Human Interest, (Boston: Beacon Press), h. 313. Lihat juga Fahry Ali dan Bahtiar Effendy, Merambah Jalan Baru Islam Rekonstruksi Pemikiran Islam Masa Orde Baru, (Bandung: Mizan, 1986), h.9.

\section{Konfigurasi Politik Hukum Islam dan Karakter Produk Hukum Islam}

Hukum adalah produk politik ${ }^{16}$ sehingga manakala membahas politik hukum cenderung mengedepankan pengaruh politik atau pengaruh sistem politik terhadap pembangunan dan perkembangan hukum. ${ }^{17}$ Hukum adalah hasil tarik-menarik pelbagai kekuatan politik yang mengejawantah dalam produk hukum. Satjipto Raharjo menyatakan bahwa hukum adalah instrumentasi dari putusan atau keinginan politik sehingga pembuatan peraturan perundang-undangan sarat dengan kepentingan-kepentingan tertentu. Dengan demikian, medan pembuatan UU menjadi medan perbenturan dan kepentingan-kepentingan. Badan pembuat UU akan mencerminkan konfigurasi kekuatan dan kepentingan yang ada dalam masyarakat. ${ }^{18}$

Konfigurasi kekuatan dan kepentingan badan pembuat UU menjadi penting karena pembuatan UU modern bukan sekadar merumuskan materi hukum secara baku berikut rambu-rambu yuridisnya, melainkan membuat keputusan politik. Di samping konfigurasi itu, intervensi-intervensi dari eksternal maupun internal pemerintahan bahkan kepentingan politik global secara tidak langsung ikut memberikan warna dalam proses pembentukan UU. Intervensi tersebut dilakukan terutama oleh golongan yang memiliki kekuasaan dan kekuatan, baik secara sosial, politik maupun ekonomi. ${ }^{19}$ Karena itu, pemahaman terhadap politik hukum Islam dalam konteks bahasan ini berangkat dari asumsi bahwa sesungguhnya hukum Islam bukan sistem hukum matang yang datang dari langit dan terbebas dari dinamika sosial kemasyarakatan. Sebagaimana halnya dengan sistemsistem hukum lain, hukum Islam selain berdimensi ilahiah, juga tidak lain adalah hasil interaksi manusia dengan kondisi sosial dan politiknya. Dalam masyarakat Indonesia yang plural, hukum senantiasa hidup dan berkembang sejalan dengan dinamika perkembangan suatu masyarakat, baik dari sisi sosio-kultural maupun politik. $^{20}$

Institusi sosial apapun tidak bisa melepaskan diri

${ }^{16}$ Moh. Mahfud MD, Politik Hukum di Indonesia, cet. I, (Jakarta: LP3ES, 1998), h. 2.

${ }^{17}$ Daniel S Lev juga berpendapat bahwa yang paling menentukan dalam proses hukum adalah konsepsi dan struktur kekuasaan politik. Lihat Daniel S. Lev, Hukum dan Politik di Indonesia: Keseimbangan dan Perubahan, (Jakarta: LP3ES, 1990), h. xii.

${ }^{18}$ Satjipto Raharjo, Sosiologi Hukum, Perkembangan, Metode dan Pilihan Masalah, (Surakarta: Muhammadiyah University Press, 2002), h. 126.

${ }^{19}$ Satjipto Raharjo, Sosiologi Hukum, h. Iтт.

${ }^{20}$ N.J. Coulson, A History of Islamic Law, (Edinburgh: Edinburgh University Press, 1991), h. 1. 
dari pengaruh lingkungan sosial dan politik yang mengitarinya, baik hukum itu sendiri maupun lembagalembaga sosial lainnya, termasuk hukum Islam dan lembaganya. Begitu pula dalam konteks upaya pengundangan hukum Islam menjadi UU negara ${ }^{21}$ harus terlebih dahulu memenangkan pertarungan sosial politik dan bahkan harus melalui proses politik di lembaga legislatif. Suatu kelompok masyarakat yang dominan dan dekat dengan kekuasaan politik maka akan terbuka peluang untuk memperoleh kekuasaan dalam menerapkan hukum tertentu sesuai dengan aspirasi dan pemikiran politiknya. Pertarungan dinamika politik inilah yang kemudian menyebabkan perubahan produk suatu hukum. Dimana penguasa membuat UU yang diciptakan untuk memperkuat kekuasaan, tetapi suatu saat dapat pula menjadi bumerang di mana pada era tertentu dapat memukul balik kekuasaan itu sendiri. Menurut Yusril Ihza Mahendra, peliknya hubungan hukum dengan kekuasaan terletak pada dua relasi dilematis. Di satu pihak, hukum harus mendasari kekuasaan, sementara di pihak lain kekuasaan itu pula yang menciptakan hukum. Filsafat hukum memang mengajarkan rechtsidee, yaitu cita hukum yang harus membimbing arah perumusan norma-norma hukum. Cita hukum Indonesia ialah Pancasila, sebagaimana terkandung di dalam pembukaan UUD 1945. Salah satu norma paling mendasar di dalam cita hukum itu ialah cita tentang keadilan. Artinya, hukum yang diciptakan harus hukum yang adil bagi semua pihak, ${ }^{22}$ termasuk adil dalam memenuhi aspirasi politik dan hukum yang menjadi kebutuhan sebagian besar masyarakat Indonesia, diantaranya yang beragama Islam.

Sekadar untuk melihat bagaimana interaksi elit politik dalam menyikapi dan bersikap terhadap hukum Islam dapat dilihat dalam proses pengundangan UU No. 17 Tahun 1999 tentang Penyelenggaraan Ibadah Haji. UU ini dirumuskan dapat dikelompokkan pada konfigurasi yang demokratis dengan beberapa indikator penting. Pertama, partai politik dari badan perwakilan berperan aktif menentukan hukum negara atau politik nasional, maka UU No. 17 Tahun 1999 tentang Penyelenggaraan Ibadah Haji lembaga legislatif mengajukan usul inisiatif DPR menjadi UU. Dengan demikian ini berarti secara prosedural politik memenuhi salah satu pilar demokrasi, yakni peran aktif wakil rakyat dalam proses legislasi RUU penyelenggaraan Haji di

\footnotetext{
${ }^{21}$ N.J. Coulson, A History of Islamic Law, h. 149.

22 Yusril Ihza Mahendra, Dinamika Tata Negara Indonesia: Kompilasi Aktual Masalah Konstitusi Dewan Perwakilan dan Sistem Kepartaian, (Jakarta: Gema Insani Press, 1996), h. 91.
}

parlemen. Kedua, supremasi rakyat di atas kepentingan penguasa. Ketiga, menjunjung tinggi pelaksanan hukum, termasuk hukum agama sebagaimana dijamin oleh UU Dasar 1945. Maka UU No. 17 Tahun 1999 tentang penyelenggaraan Haji dapat dikatakan sebagai wujud dari pengamalan Pancasila dan UU Dasar 1945. Keempat, peran eksekutif menghormati kehendak rakyat dan melaksanakan kebijakan yang pro-rakyat seperti pengundangan UU No. 17 Tahun 1999 tentang Penyelenggaraan Ibadah Haji.

Bila diperhatikan dari empat indikator di atas, maka konfigurasi politik ketika produk UU No. 17 Tahun 1999 tentang Penyelenggaraan Ibadah Haji yang direpresentasikan maka empat pilar demokrasi yang disebut di atas semua unsurnya terpenuhi. Sedangkan dari aspek karakter produk hukum sepenuhnya dapat dikelompokkan pada karakter hukum yang responsif karena produk hukumnya telah mencerminkan rasa keadilan dan memenuhi harapan masyarakat di bidang ibadah umat Islam. Dalam proses pembuatannya memberikan peranan besar dan partisipasi penuh kelompokkelompok sosial atau individu di dalam masyarakat. Hasilnya bersifat responsif terhadap tuntutan-tuntutan kelompok sosial atau individu dalam masyarakat. Dengan demikian, maka konfigurasi politik ketika lahirnya UU No. 17 Tahun 1999 tentang Penyelenggaraan Ibadah Haji dalam konfigurasi politik demokratis dan dengan produk hukum Islam yang responsif, sebagaimana digambarkan dalam diagram berikut ini.

Karakter Produk Hukum UU Penyelenggaraan Hajii ${ }^{23}$

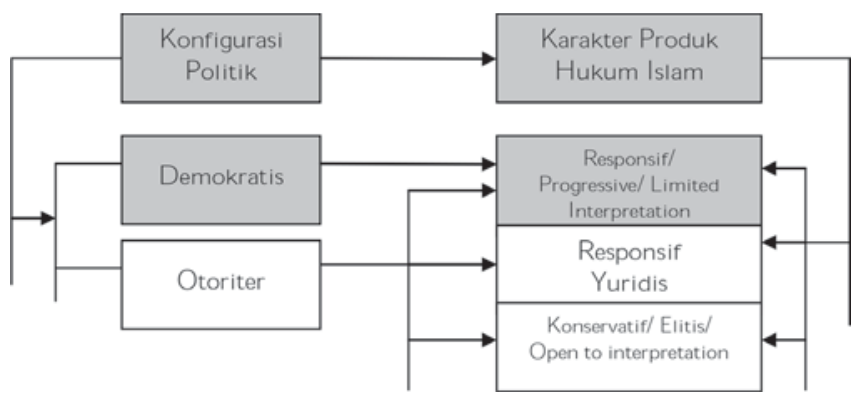

Tidak jauh berbeda, dalam proses pengundangan UU No. 38 Tahun 1999 tentang Pengelolaan Zakat. UU ini lahir ketika pemerintahan B.J. Habibie sedang membuka seluas-luasnya peran dan partisipasi kelompok masyarakat sehingga secara politik konfigurasi politiknya bersifat demokratis. Bila diperhatikan dari empat

${ }^{23}$ Diadaptasi dari Moh. Mahfud MD, Politik Hukum di Indonesia, (Jakarta: LP3ES, 1998), h. 15 dan Afan Gaffar, "Pembangunan Hukum dan Demokrasi”, dalam M. Busyro Muqoddas dkk., Politik Pembangunan Hukum Nasional, (Yogyakarta: UII, 1992), h. 109. 
indikator di atas, maka konfigurasi politik ketika produk UU No. 38 Tahun 1999 tentang Pengelolaan Zakat yang direpresentasikan maka empat pilar demokrasi yang disebut di atas semua unsurnya terpenuhi. Sedangkan dari aspek karakter produk hukumnya sepenuhnya dapat dikelompokkan pada karakter hukum yang responsif karena produk hukumnya telah mencerminkan rasa keadilan dan memenuhi harapan masyarakat di bidang ibadah umat Islam. Dalam proses pembuatannya memberikan peranan besar dan partisipasi penuh kelompokkelompok sosial atau individu di dalam masyarakat. Hasilnya bersifat responsif terhadap tuntutan-tuntutan kelompok sosial atau individu dalam masyarakat.

Hal yang menarik juga dapat dilihat dari proses lahirnya UU No. 18 Tahun 2001, kebijakan yang dilakukan adalah melanjutkan kebijakan otonomi khusus daerah Aceh yang telah dimulai pada masa B.J. Habibie. B.J. Habibie telah meletakkan pondasi Otda bagi daerah Aceh dengan mengeluarkan UU No. 44 Tahun 1999 yang disahkan pada tanggal 23 September 1999, yang mengatur tentang Penyelenggaraan Keistimewaan. Mengawali keluarnya UU No. 44 Tahun 1999 di kalangan masyarakat Aceh muncul pelbagai tuntutan, seperti menuntut pemberlakuan syariat Islam sesuai dengan keistimewaan Aceh, atau bahkan tuntutan mengadakan referendum. Pada tanggal 13 Januari 1999 Angkatan Intelektual Darussalam mengeluarkan pernyataan politik yang mengimbau dilaksanakan referendum di Aceh untuk menyelesaikan konflik. Demikian pula tuntutan yang sama diajukan berdasarkan hasil Kongres Mahasiswa dan Pemuda Aceh Serantau yang diadakan di Banda Aceh pada 31 Januari sampai 4 Februari 1999. Tuntutan ini mungkin diilhami oleh keberhasilan referendum di Timor Timur yang membuat bekas Provinsi RI itu menjadi sebuah negara yang merdeka. ${ }^{24}$

Pemerintah Pusat merespons pelbagai tuntutan itu dengan mengundangkan UU No. 44Tahun 1999 tentang Penyelenggaraan Keistimewaan Provinsi Daerah Istimewa Aceh yang bermula dari pengajuan usul inisiatif sejumlah anggota DPR asal Aceh. Dalam UU yang memuat 13 pasal ini dijelaskan ada lima ranah keistimewaaan atau Otonomi Khusus Bagi Aceh. Pertama, penyelenggaraan kehidupan beragama dengan penerapan syariat Islam dalam seluruh aspek kehidupan beragama. Kedua, penyelenggaraan kehidupan adat dengan memasukkan unsur adat dalam struktur pemerintahan desa, misalnya penyebutan pada desa menjadi keuchik(lurah) dan mukim

${ }^{24}$ Taufik Adnan Amal dan Samsu Rizal Panggabean, Politik Syariat Islam dari Indonesia hingga Nigeria, (Jakarta: Alvabet, 2004), h.25. untuk kumpulan beberapa desa. Ketiga, penyelenggaraan pendidikan dengan menggunakan kurikulum pendidikan berdasarkan syariat tanpa mengabaikan kurikulum umum. Keempat, peranan ulama dalam penetapan kebijakan daerah dengan pengakuan peran ulama dalam penetapan kebijakan daerah (Pasal 3 ayat [2] UU No. 44 Tahun 1999). Inilah kebijakan yang kemudian menjadi pintu masuk pelaksanaan syariat Islam di Aceh dan lahirnya institusi peradilan yang disebut sebagai Mahkamah Syar' iyah serta pelbagai qanun yang mengatur materi-materi hukum Islam yang dijadikan rujukan dalam menjalankan tugas dan kewenangan Mahkamah Syar'iyyah. Sebagai pelaksanaan dari UU ini pemerintah daerah mengeluarkan Peraturan Daerah Provinsi Daerah Aceh No. 5 Tahun 2000 tentang pelaksanaan Syariat Islam. Peraturan Daerah ini menegaskan tentang hak-hak istimewa yang diberikan pada Provinsi Daerah Istimewa Aceh berdasarkan UU No. 44 Tahun 1999 agar dapat diterapkan di tengah-tengah masyarakat secara luas.

Dalam proses pengundangan UU No. 18 Tahun 2001 tentang Otonomi Khusus bagi Provinsi Daerah Istimewa Aceh sebagai Provinsi Nanggroe Aceh Darussalam kondisi sosial politik sedang menikmati eforia kebebasan berdemokrasi dan Otda, di mana terhadap daerah-daerah yang sedang konflik diberikan otonomi khusus, seperti Provinsi Timor Timur yang akhirnya memperoleh kemerdekaan melalui referendum. Dalam konteks Aceh, pemerintah pusat menghadapi kesulitan dalam penyelesaian konflik bersenjata dari Gerakan Aceh Merdeka (GAM). Salah satu solusinya adalah memberikan otonomi khusus dengan memberikan keistimewaan terutama dalam menjalankan syariat Islam. Bila dilihat dari konfigurasi politik yang diperankan pemerintah, maka dalam proses keluarnya UU No. 18 Tahun 2001 dapat disebut konfigurasi politik demokratis karena beberapa indikator penting dapat terpenuhi. Pertama, partisipasi partai politik dari badan perwakilan dan pemerintah berperan aktif menentukan hukum negara atau politik nasional dalam memberikan solusi bagi penyelesaian konflik Aceh dengan munculnya usul inisiatif RUU tentang Otonomi Khusus bagi Provinsi Daerah Istimewa Aceh sebagai Provinsi Nanggroe Aceh Darussalam. Dengan demikian ini berarti telah memenuhi salah satu pilar demokrasi, yakni peran aktif wakil rakyat dalam proses legislasi UU tentang Otonomi Khusus Bagi Provinsi Daerah Istimewa Aceh sebagai Provinsi Nanggroe Aceh Darussalam di parlemen.

Kedua, disetujuinya RUU Otonomi Khusus berarti supremasi rakyat di atas kepentingan penguasa semakin terpenuhi karena secara substansial dengan di- 
berlakukannya Mahkamah Syar'iyyah, maka tercapailah cita-cita luhur masyarakat Aceh untuk menerapkan kehidupan pribadi, keluarga, dan masyarakat berdasarkan nilai dan ajaran Islam di tengah kemajemukan bangsa Indonesia. ${ }^{25}$

Ketiga, dalam hal pilar menjunjung tinggi pelaksanan hukum, maka pemberian kesempatan untuk menerapkan syariat Islam di Aceh sama artinya bahwa negara telah menghargai hukum agama sebagaimana dijamin oleh UU Dasar 1945. Maka Otonomi Khusus bagi Provinsi Daerah Istimewa Aceh sebagai Provinsi Nanggroe Aceh Darussalam dapat dikatakan sebagai wujud daripada pengamalan Pancasila dan UU Dasar 1945 dalam masyarakat yang memiliki pluralis hukum.

Keempat, peranan eksekutif menghormati kehendak rakyat dan melaksanakan kebijakan yang pro-rakyat karena Otonomi Khusus bagi Provinsi Daerah Istimewa Aceh sebagai Provinsi Nanggroe Aceh Darussalam merupakan utang pemerintah sejak awalawal kemerdekaan yang harus dibayar, tanpa harus mengorbankan Negara Kesatuan Republik Indonesia.

Bila diperhatikan dari empat indikator di atas, maka konfigurasi politik ketika produk UU No. 18 Tahun 2001 tentang Otonomi Khusus bagi Provinsi Daerah Istimewa Aceh sebagai Provinsi Nanggroe Aceh Darussalam direpresentasikan dengan adanya dukungan partai politik, pemerintah, dan unsur lainnya maka empat pilar-pilar demokrasi yang disebut di atas semua unsurnya terpenuhi. Sedangkan dari aspek karakter produk hukumnya sepenuhnya dapat dikelompokkan pada karakter hukum yang responsif karena produk hukumnya telah mencerminkan rasa keadilan dan memenuhi harapan masyarakat, terutama kebutuhan hukum masyarakat Nanggroe Aceh Darussalam. Baik UU No.44 Tahun 1999 tentang Penyelenggaraan Keistimewaan di Provinsi Daerah Istimewa Aceh maupun UU No.18 Tahun 2001 tentang Otonomi Khusus bagi Provinsi Daerah Istimewa Aceh sebagai Provinsi Nanggroe Aceh Darussalam adalah merupakan perjuangan masyarakat Aceh yang sangat penting dan fundamental karena UU tersebut sebagai pintu bagi pembentukkan peradilan syariat Islam di Aceh, yang kemudian disebut Mahkamah Syar'iyah.

Produk UU ini sangat tepat disebut produk hukum

25 Sambutan Pemerintah pada Pembicaraan Tingkat IV/ Pengambilan Keputusan Atas Rancangan Undang-undang Tentang Otonomi Khusus Bagi Provinsi Daerah Istimewa Aceh Sebagai Provinsi Nanggroe Aceh Darussalam dalam siding Paripurna Dewan Perwakilan Rakyat Republik Indonesia tanggal 19 Juli 2001 yang diwakili Menteri Dalam Negeri dan Otda, Surjadi Soedirdja, h. 10. yang berkarakter responsif karena lahir dari konfigurasi politik yang demokratis dan telah mencerminkan rasa keadilan dan memenuhi harapan masyarakat, khususnya masyarakat Nanggroe Aceh Darussalam. Meski ditakuti pada awalnya, pemberlakuan syariat Islam di Nanggroe Aceh Darussalam ditujukan untuk mencegah agar Aceh tidak memisahkan diri dari Negara Kesatuan Republik Indonesia. Dari sudut itu, proses pemberlakuan syariat Islam di Aceh bukan suatu proses yang genuine dan alamiah, tetapi lebih merupakan suatu gerakan dan kebijakan politik dalam rangka mencegah Aceh dari upaya memisahkan diri dari Negara Kesatuan Republik Indonesia. ${ }^{26}$ Dalam proses pembuatan UU ini lembaga politik memberikan peranan besar dan partisipasi penuh kelompok-kelompok sosial atau individu di dalam masyarakat.

\section{Teori Konstitusi dan Teori Akomodasi}

Kebijakan transformasi hukum Islam ke dalam hukum nasional tidak memiliki hubungan dengan perjuangan untuk menuju negara Islam atau Islam sebagai dasar negara. Tetapi sebaliknya, legislasi hukum Islam menjadi perundang-undangan negara memiliki kontribusi positif dalam memperkuat daya rekat umat Islam terhadap komitmen negara kebangsaan (nation state) karena syariah bisa berjalan seiring dan kompatibel dengan Pancasila dan UUD 1945. Hukum Islam tidak harus dilihat dalam kerangka misiologi, tetapi dalam kerangka fenomenologi konstitusional untuk membangun hukum nasional Indonesia.

Kajian ini membantah temuan Price bahwa mengenai proses transformasi syariat Islam ke dalam perundangundangan negara dan dalam kehidupan sosial masyarakat dianggap bagian penting menuju negara Islam melalui lima level. Pertama, syariat Islam berlaku pada bidang hukum kekeluargaan seperti perkawinan, perceraian, dan warisan. Kedua, syariat Islam berlaku pada bidang ekonomi dan keuangan seperti bank Islam dan zakat. Ketiga, syariat Islam berlaku pada praktik-praktik ritual keagamaan seperti kewajiban mengenakan jilbab bagi wanita atau pelarangan secara resmi terhadap halhal yang bertentangan dengan ajaran Islam seperti alkohol dan perjudian. Keempat, syariat Islam berlaku juga pada penerapan hukum pidana Islam terutama berkenaan dengan jenis-jenis sanksi yang dijatuhkan bagi pelanggarnya. Kelima, penggunaan Islam sebagai

${ }^{26}$ Azyumardi Azra, "Syariat Islam dalam Bingkai Nation State", dalam Komaruddin Hidayat dan Ahmad Gaus (eds), Islam Negara \& Civil Society Gerakan dan Pemikiran Islam Kontemporer, (Jakarta: Paramadina, 2005), h. 35. 
dasar negara dan sistem pemerintahannya. Kelima level ini berlaku secara hirarkis dari terendah sampai pada yang tertinggi. Semakin tinggi level tuntutan penerapan hukum Islam, maka semakin dekat menuju gagasan negara Islam. ${ }^{27}$ Dengan kata lain, semakin tinggi level tuntutan penerapan hukum Islam, maka semakin dekat menuju bentuk negara Islam. Penilaian ini bersifat apriori-hipotetis dan skeptis karena pemberlakuan syariat Islam harus merujuk pada konstitusi negara, Pancasila, Negara Kesatuan Republik Indonesia (NKRI), serta Pembukaan (Preamble) UUD 1945 sebagai bentuk final dari komitmen kebangsaan umat Islam Indonesia khususnya dan bangsa Indonesia pada umumnya.

Tulisan ini juga memperlihatkan konfigurasi dan pola-pola interaksi pusat-pusat kekuasaan (power points) di seputar hiruk-pikuk hukum Islam di Indonesia dipengaruhi oleh tiga faktor penting yaitu, pertama aspek situasi konfigurasi politik yang terdiri atas konfigurasi politik demokratis dan otoriter. Tesis ini menolak teori konfigurasi politik hukum yang diajukan Benny K. Harman dan Mahfud $\mathrm{MD}^{28}$ tentang konfigurasi politik demokratis dan konfigurasi politik otoriter akan menghasilkan produk hukum responsif dan konservatif. Dalam konteks hukum Islam, konfigurasi politik tidak secara signifikan ikut mempengaruhi substansi produk hukum Islam yang diundangkan, tetapi bila dilihat dari segi proses politik dapat mengikuti konfigurasi politik. Dari aspek karakter hukum ada beberapa kemungkinan produk yang lahir. Pertama, responsif yang berarti secara politis produk hukum ini lahir secara demokratis dan secara yuridis sejalan dengan substansi hukum Islam yang dianut umat Islam Indonesia dan dalam mekanisme pengundangannya bersifat pluralistic/kompetitif. Kedua, responsif-yuridis/politis, artinya secara politik produk hukum Islam yang lahir tidak dalam konfigurasi politik demokratis atau bahkan berada dalam konfigurasi politik otoriter, tetapi dipandang dari substansial memenuhi syarat minimal dari substansi hukum Islam atau minimal tidak bertentangan dengan hukum Islam. Ketiga, konservatif, yakni produk hukum Islam yang jelas-jelas bertentangan dengan substansi hukum dan mekanisme lahirnya cenderung sentralistik. Tesis ini membuktikan bahwa

${ }^{27}$ Arskal Salim and Azyumardi Azra (eds), Shariá and Politics in Modern Indonesia, diedit oleh Arskal Salim dan Azyumardi Azra, (Singapore: ISEAS, 2003). Lihat Arskal Salim, "Syariat Sampai Level Mana?", Harian Sumut Post, 12 April 2002. Lihat juga Rusjdi Ali Muhammad, Revitalisasi Syari'at Islam di Aceh Problem, Solusi dan Implementasi Menuju Pelaksanaan Hukum Islam di Nanggroe Aceh Darussalam, (Jakarta: Logos dan Ar-Raniry Press, 2003), h. 227.

28 Moh. Mahfud MD, Politik Hukum di Indonesia, (Jakarta: LP3ES, 1998), h.15. dalam konfigurasi demokratis dan konfigurasi politik otoriter bisa lahir karakter produk hukum responsif tetapi tidak sebaliknya, karena dalam perspektif siyâsah shariyyah pasti melahirkan produk hukum yang al-ádilah/responsif, sedangkan siyâsah wad'iyyah dimungkinkan melahirkan produk hukum yang al-âdilah (responsif) atau al-zâlimah (konservatif). Hal ini dijelaskan antara lain oleh 'Abd alRahmân Tâj, ${ }^{29}$ 'Abd al-Wahhâb Khallâf, ${ }^{30}$ dan Muhammad Diyâ al-Dîn al-Rîs. ${ }^{31}$

Kedua, politik hukum Islam di Indonesia bila dilihat dari faktor isi produk undang-undang mengenai hukum Islam yang lahir dari model negara Indonesia dapat bersifat responsif dan konservatif. Bila model negara Indonesia dilihat dengan perspektif 'Abd al-Rahmân Tâj, 'Abd al-Wahhâb Khallâf, dan Muhammad Diyâ al-Dîn al-Rîs, maka Indonesia dapat disebut menganut sistem siyâsah wad'iyyah yang melahirkan dua kemungkinan produk hukum, yakni al-âdilah dan al-zâlimah atau responsif dan konservatif. Untuk membuktikan responsif atau konservatifnya produk hukum yang dijadikan studi kasus dalam kajian ini, maka UU No. 1 Tahun 1974 tentang Perkawinan yang lahir pada saat konfigurasi politik di Indonesia sedang berada dalam konfigurasi politik otoriter, tetapi karakter produk hukum Islam ini ternyata bersifat responsif. Dari segi isi UU ini disebut responsif karena seluruh pasal-pasal yang termaktud dalam UU No.1 Tahun 1974 Tentang Perkawinan telah sejalan dengan hukum Islam atau sekurang-kurangnya tidak bertentangan dengan hukum Islam. Begitu juga produk hukum UU No. 7 Tahun 1989 tentang Peradilan Agama, dari perspektif pembentukkan hukum berkarakter responsif karena akomodatif terhadap lembaga pengadilan agama yang menjadi bagian penting dalam kelembagaan hukum Islam di Indonesia, namun ia lahir saat-saat konfigurasi politik otoriter. Hal yang sama juga pada Kompilasi Hukum Islam, konfigurasi politik pemerintahan Orde Baru masih dinilai tidak demokratis, sementara dari segi isi sepenuhnya berisi ketentuan-ketentuan yang diangkat dari kitab-kitab fikih rujukan umat Islam yang memuat aspek hukum perkawinan Islam, kewarisan, dan perwakafan. Sedangkan masa Era Reformasi substansi dari produk hukum UU No. 17 Tahun 1999 tentang Penyelenggaraan Ibadah Haji, UU No. 38 Tahun 1999 Tentang Pengelolaan Zakat, UU No. 18 Tahun 2001

29 'Abd al-Rahmân Tâj, al-Siyâsah al-Shar'iyyah wa al-Fiqh alIslâmî, (Mesir: Mathba'ah Dâr al-Tảlîf, 1953), h. 7-12.

30 'Abd al-Wahhâb Khallâf, al-Siyâsah al-Shar'iyyah, (Qâhirah: Dâr al-Anșâr, 1977), h. 4.

${ }^{31}$ Muhammad Diyâ al-Dîn al-Rîs, Al-Nażariyyât al-Siyâsah alIslamiyyah, (Qâhirah: Dâr al-Mâârif, 1967), h. 280-292. Lihat juga 'Abd al-Wahhâb Khallâf, al-Siyâsah al-Shar'iyyah, h. 24. 
tentang OTSUS NAD, UU No. 41 Tahun 2004 tentang Wakaf, UU No. 3 Tahun 2006 tentang Amandemen terhadap UU No. 7 Tahun 1989 tentang Peradilan agama dan UU Perbankan Syariah Tahun 2008 sepenuhnya sejalan dengan hukum Islam karena secara substansial untuk memperbaiki sistem manajemen masalah ibadah haji, zakat, wakaf, dan otonomisasi hukum Islam di wilayah Nanggroe Aceh Darussalam, perluasan absolut kompetensi peradilan agama di bidang ekonomi syariah dan perbankan syariah. Sedangkan kebijakan-kebijakan bidang hukum pidana umum yang berlabel hukum positif, negara akomodatiif karena yang dimasukkan adalah nilainilai dasar Islam yang bersifat universal dan dapat berlaku bagi semua masyarakat baik muslim maupun non muslim. Sebagai contoh misalnya UU No. 7 Tahun 1996 tentang Pangan, UU No.3 Tahun 1997 tentang Pengadilan Anak, UU No. 39 Tahun 1999 tentang Hak Asasi Manusia, UU No. 23 Tahun 2002 tentang Perlindungan Anak dan UU No. 20 Tahun 2003 tentang Sistem Pendidikan Nasional dan termasuk sebagaian dari hukum positif bidang hukum pidana dan perdata umum yang dinilai sejalan dengan hukum Islam atau sekurang-kurangnya tidak bertentangan dengan hukum Islam.

Berdasarkan bukti-bukti karakter produk hukum Islam khususnya masa Orde Baru yang bersifat responsif, maka tesis ini juga mempertanyakan periodisasi hubungan Islam dan negara masa Orde Baru yang diajukan Bahtiar Effendy. ${ }^{32}$ Studi ini menemukan nuansa berbeda bila studi menggunakan perspektif politik hukum untuk memposisi konfigurasi politik hukum Islam masa Orde Baru. Dalam perspektif temuan studi politik, hubungan Islam dan negara pada pemerintahan Presiden Soeharto dinilai terdapat pola atau periode antagonistik [1967-1982], resiprokal kritis [1982-1985], dan akomodatif [1985-1994]. Penilai antagonistik pada masa-masa awal Orde Baru hanya tepat untuk menggambarkan hubungan Islam politik dan negara Orde Baru karena bersimpang jalannya kepentingan antara kepentingan Islam politik dengan politik pemerintahan Orde Baru yang berorientasi pada penguatan modernisasi pembangunan, kebangsaan dan ke-Indonesiaan, sementara Islam politik berorientasi pada formalistik agama untuk membuka ruang yang seluas-luasnya bagi Islam politik, termasuk mengenai ideologi negara. Bila periode yang sama dilihat dari aspek politik hukum Islam, maka justru pemerintahan Presiden Soeharto pada era awal-awal pemerintahannya sangat akomodatif terhadap aspirasi hukum Islam di

32 Bahtiar Effendy, Islam dan Negara Transformasi Pemikiran dan Praktik Politik Islam di Indonesia, (Jakarta: Paramadina, 1998).
Indonesia yang ditandai lahirnya kebijakan-kebijakan pro hukum Islam dan lembaganya, diantaranya UU No. 14 Tahun 1970 tentang Pokok-Pokok Kekuasaan Kehakiman, Undang-Undang No.1 Tahun 1974 tentang Perkawinan dan PP No. 9 Tahun 1975 tentang Pelaksanaan Undang-Undang Perkawinan, PP No. 28 Tahun 1977 tentang Perwakafan Tanah Milik pada tahun 1975 dan kebijakan-kebijakan lainnya terutama menyangkut bidang ibadah dan muamalah.

Terjadinya akomodasi Orde Baru terhadap umat Islam dilandasi dengan fondasi bangunan politik negara dengan memakai konsep dasar negara Pancasila dan mensejalankannya dengan nilai-nilai Islam, kemudian diikuti dengan membangun konsep kerukunan umat beragama di Indonesia dengan pendekatan top-down. Sedangkan di Era Reformasi, fondasi kuat terbangun melalui amandemen UUD 1945 dengan diakuinya peradilan agama dalam UUD 1945 serta semakin luasnya absolut kompetensi peradilan agama yang meliputi masalah ekonomi syariah, otonomisasi hukum Islam di Nanggroe Aceh Darussalam (NAD) dan lahirnya UU Perbankan Syariah Tahun 2008. Dengan perluasan bidang pemberlakuan hukum Islam ini maka dapat dikatakan bahwa lebih dari $2 / 3$ dari materi fikih yang terdapat dalam kitab-kitab fikih telah dilaksanakan oleh umat Islam Indonesia baik ajaran yang berada dalam kelompok diyânî maupun qad $\underline{a} \hat{\imath}$. Politik hukum di Era Reformasi dalam bidang ibadah dan muamalah bersifat akomodatif, dan bidang jinâyah (pidana/criminal law/ hudîd) bersifat akomodatif-politis, dengan pendekatan bottom up seperti kasus Nanggroe Aceh Darussalam sebagai religious approach dalam menyelesaikan konflik Aceh. Bagi Tim Lindsey, M.B Hooker, Ross Clarke, dan Jeremy Kingsley, fenomena kebangkitan syariah di Aceh adalah perubahan radikal di Indonesia dan perkembangan syariah selanjutnya sangat ditentukan politik pemerintahan dari Jakarta. ${ }^{33}$

Ketiga, politik hukum Islam di Indonesia dilihat dari faktor orang atau kelompok pendukung atau penentang yang terdiri atas nasionalis Islam, nasionalis religius, dan nasionalis sekuler. Studi ini menunjukkan bahwa konflik nasionalis sekuler dan nasionalis Islam menjelma ketika terjadi interaksi antara pusat-pusat kekuasaan (power points) baik di tingkat infrastruktur maupun suprastruktur di tengah-tengah masyarakat

${ }^{33}$ Tim Lindsey , M.B. Hooker, Ross Clarke, dan Jeremu Kingsley, "Shariá Revival in Aceh,", dalam Islamic Law in Contemporary Indonesia: Ideas and Institutions, diedit oleh R. Michael Feener and Mark E. Commack, (Cambridge, Massachusettes: Islamic Legal Studies Program, Harvard Law School, 2007), h. 253-254. 
dalam proses perumusan dasar negara dan proses legislasi hukum Islam di Indonesia. Pada masa Orde Baru dalam proses transformasi hukum Islam ke dalam hukum nasional pola-pola interaksi melahirkan dua kelompok penentang (nasionalis sekuler) dan pendukung (nasionalis Islam). Hal ini sejalan dengan studi Nadirsyah Hosen yang mengedepankan posisi syariah dalam UU Dasar di Indonesia melahirkan dua aliran pemikiran, yakni fundamentalis dan sekuler yang menyatakan bahwa syariah tidak compatible dengan UUD dan kelompok yang berpendapat bahwa syariah bisa berjalan seiring dengan UUD. Kelompok ini terbagi dua yakni formalistik dan substantif. Sedangkan Era Reformasi jarak antara nasionalis sekular dan nasionalis Islam semakin menipis dan bahkan nasionalis sekuler kemudian merubah nama menjadi kelompok nasionalis religius sebagai label kelompok ini. Nasionalis religius dan nasionalis Islam melakukan sinergi tanpa harus terjebak dalam masalah isu-isu menuju negara Islam dan Piagam Jakarta. Mencairnya hubungan antara dua kubu pemikiran di atas karena pergeseran paradigma berpikir umat Islam dari formalistik menuju substansif di satu pihak, dan perubahan pemahaman di tingkat infrastruktur, seperti partai politik, parlemen, ormas/ LSM, dan media massa dalam memahami Islam dan kaitannya dengan negara. Hal ini juga ikut membantu perkembangan pemikiran hukum Islam yang sedang berkembang menuju penciptaan mazhab hukum Islam Indonesia. Tesis ini sejalan dengan M.B Hooker ${ }^{34}$ dan Michael Feener ${ }^{35}$ yang menyatakan bahwa syariah di Indonesia adalah work in progress menuju hukum Islam Indonesia. Proses pembentukkan hukum Islam mazhab Indonesia sebagai kontribusi penting dari pemerintah, cendekiawan/ulama, lembaga swadaya masyarakat, lembaga pendidikan seperti pesantren, UIN/IAIN, dan pelbagai aspek lainnya. Mainstream utama perkembangan pemikiran ini adalah menjadikan nilai-nilai agama sebagai etika publik dan bila melakukan legislasi hukum Islam harus melalui mekanisme konstitusional yang demokratis.

Studi ini membangun suatu teori yang menyatakan bahwa konfigurasi politik demokratis memberi ruang

${ }^{34}$ M.B Hooker, Indonesian Syariah: Defining a National School of Islamic Law, (Singapore: ISEAS, 2008), h. 285. Hooker sebelumnya telah menerbitkan buku Indonesian Islam: Social Change througth Contemporary Fatawa yang melihat ke-khas-an Islam di Indonesia melalui kajian terhadap pelbagai fatwa. Buku ini pun sebenarnya adalah kelanjutan beberapa kajian yang dilakukannya terhadap Hukum Islam di Asia Tenggara termasuk Indonesia, seperti terlihat pada Islamic Law in South-East Asia.

${ }^{35}$ R. Michael Feener, Muslim Legal Thought in Modern Indonesia, (Cambridge: Cambridge University Press. 2007), h. 222-227. yang luas bagi transformasi hukum Islam ke dalam hukum nasional dengan karakter produk hukum yang responsif. Semakin demokratis suatu negara maka akan semakin memperkecil potensi terjadinya konflik di antara nasionalis sekuler (nasionalis religius) dan nasionalis Islam. Sebagai standar untuk mengukur konfigurasi politik demokratis atau otoriter bergantung pada terpenuhinya pilar-pilar demokrasi di tingkat infrastruktur maupun suprastruktur. Untuk mengukur dari segi isi dan sifat suatu produk hukum apakah responsif atau konservatif dapat lihat dari segi sejauh mana aturan-aturan sejalan dengan hierarki perundangundangan, sejalan dengan hukum Islam atau sekurangkurangnya tidak bertentangan nilai-nilai ajaran Islam atau bertentangan dengan dasar negara, Pancasila, dan UUD 1945.

Transformasi nilai-nilai hukum Islam merupakan kewajiban konstitusional negara dalam membangun sistem hukum nasional di Indonesia yang bersumber dari tiga sumber hukum, yakni: hukum adat, hukum positif (Belanda), dan hukum Islam. Ketiga sub-sistem hukum ini merupakan the living law bagi masyarakat dan bangsa Indonesia berdasarkan konstitusi negara yang tercermin dalam Pembukaan UUD 1945. Pasal 29 UUD 1945 menyatakan bahwa Indonesia bukan negara agama, tetapi Indonesia adalah Republik beragama, yakni negara mengakui agama resmi, yakni Islam, Katolik, Protestan, Hindu, dan Budha, bukan negara sekuler. Dalam konteks politik hukum, maka negara wajib mengangkat nilai-nilai hukum dari agama-agama yang diakui oleh negara secara resmi-bila agama-agama itu memiliki sistem hukum, untuk membangun sistem hukum nasional Indonesia melalui mekanisme konstitusional. Dalam kaitannya dengan hukum Islam sebagai the living law, maka adopsi hukum Islam dalam hukum nasional merupakan kewajiban berdasarkan amanah konstitusi UUD 1945 melalui mekanisme politik yang demokratis atau minimal hukum Islam harus menjadi referensi bagi pembentukan hukum nasional di Indonesia. Proses transformasi hukum Islam menjadi hukum nasional ini dinamai sebagai teori konstitusi (the constitution theory) dan teori akomodasi (the accomodation theory). Teori konstitusi yang dimaksud dalam kerangka politik hukum di sini adalah transformasi nilai-nilai hukum agama ke dalam hukum nasional Indonesia merupakan kewajiban berdasarkan konstitusi negara (obligation by constitution) untuk membangun sistem hukum nasional melalui mekanisme konstitusional yang demokratis. Teori ini dibangun berdasarkan argumentasi bahwa secara struktural Undang-undang 1945 meletakkan posisi 
agama pada posisi yang tinggi. UUD 1945 mengakui dan menganut ide Ketuhanan Yang Maha Esa dalam kehidupan bermasyarakat, berbanga dan bernegara. Ide Ketuhanan Yang Maha Esa itu tidak saja ditegaskan dalam rumusan Pembukaan UUD yang menyebut secara eksplisit adanya pengakuan ini, tetapi juga dengan tegas mencantumkan ide Ketuhanan Yang Maha Esa itu sebagai sila pertama dan utama dalam rumusan Pancasila. Dalam UU No. 1 Tahun 1974 tentang Perkawinan pasal 2 telah dijelaskan bahwa, "Perkawinan adalah sah apabila dilakukan menurut masing-masing agama dan kepercayaannya itu."

Sedangkan teori akomodasi (the accomodation theory) dibangun atas argumentasi bahwa negara berkewajiban untuk mengakomodasi seluruh subsistem hukum nasional ke dalam perundang-undangan negara dengan menggunakan tolok ukur hukum Islam sebagai hukum yang dianut mayoritas masyarakat Indonesia. Perkembangan ke arah adopsi yang semakin luas terhadap sistem hukum Islam yang bersesuaian dengan dinamika kesadaran hukum dalam masyarakat Indonesia, yang dituangkan dalam pelbagai bentuk peraturan perundangundangan serta diwujudkan dalam esensi kelembagaan hukum yang dikembangkan dapat dikaitkan pula dengan pertimbangan-pertimbangan yang bersifat filosofis dan ketatanegaraan. Bila dikaitkan teori konsitusi dan teori akomodasi di atas dengan pemahaman mengenai konsep theistic democracy yang berdasar atas hukum ataupun konsep divine nomocracy yang demokratis yang berhubungan erat dengan penafsiran inovatif terhadap Alquran yang mewajibkan ketaatan kepada Allah, kepada Rasulullah, dan kepada ulul amr (Q.s. al-Nisâ'[4]: 59). Karena itu, konsep parlemen dalam pengertian modern dapat diterima dalam kerangka pemikiran Hukum Islam, melalui mana norma-norma hukum Islam itu diberlakukan dengan dukungan otoritas kekuasaan umum, yaitu melalui pelembagaannya menjadi peraturan perundang-undangan negara.

Secara akademik, teori konstitusi dan teori akomodasi mempunyai dasar pijakan yang sangat kuat. Pertama, adanya jaminan terhadap hukum agama dalam UUD 1945. Kedua, umat Islam Indonesia terbesar di dunia, sehingga Indonesia sering disebut negara muslim dan bangsa Indonesia sering disebut bangsa muslim. Ketiga, hukum Islam sebagai the living law adalah salah satu sub-sistem hukum nasional dan bernegara telah menunjukkan semakin kuatnya peran Islam di ruang publik (public sphere) dalam membangun tata hukum nasional. Keempat, iklim politik dan demokrasi di Indonesia telah memberi ruang gerak bagi transformasi hukum Islam karena sebagian besar lembaga politik didominasi umat Islam. Kelima, semakin kaburnya batas pemisah antara nasionalis sekuler dan nasionalis Islam akan memperbesar faktor akomodatif dan memperkecil dimensi konflik menuju transformasi hukum Islam dalam hukum nasional. Keenam, perkembangan pemahaman keagamaan yang semakin menuju substantif ajaran dibanding formalistik-legal. Ketujuh, perkembangan demokrasi semakin membuka ruang bagi akomodasi dan adopsi hukum Islam dalam perundang-undangan Negara. Semakin demokratis suatu pemerintahan, semakin besar pula peluang untuk mengadopsi nilai-nilai agama dalam kehidupan masyarakat berbangsa dan bernegara.

\section{Penutup}

Dalam konteks politik hukum Islam di Indonesia, teori konstitusi (the constitution theory) dan teori akomodasi (the accomodation theory) menjadi relevan untuk diajukan dalam temuan studi ini. Yakni suatu teori yang mengatakan bahwa, "Negara memiliki kewajiban konstitusional untuk mengakomodasi dan menjadikan hukum Islam sebagai referensi hukum nasional." Dengan demikian, maka semua produk perundang-undangan yang dilahirkan oleh negara harus sejalan dengan substansi nilai-nilai universal Islam dan nilai-nilai hukum Islam atau sekurangkurangnya peraturan perundangan-undangan tersebut tidak bertentangan dengan hukum Islam yang diyakini mayoritas masyarakat dan bangsa Indonesia.[]

\section{Pustaka Acuan}

Ali, Fahry dan Bahtiar Effendy, Merambah Jalan Baru Islam Rekonstruksi Pemikiran Islam Masa Orde Baru, Bandung: Mizan, 1986.

Amal, Taufik Adnan dan Samsu Rizal Panggabean, Politik Syariat Islam dari Indonesia hingga Nigeria, Jakarta: Alvabet, 2004.

Arifin, Busthanul, "Lâ Yanfa' Takallum bi Haqq lâ Nafâdha lah", Makalah pada Sarasehan Sehari IAIN Syarif Hidayatullah, Jakarta, 10 Pebruari 2000.

----------, Menghidupkan Kembali Norma-Norma Hukum Islam," Makalah pada seminar di Padang pada tanggal 27 Desember 2002.

Azhary, Muhammad Tahir, Negara Hukum Suatu Studi tentang Prinsip-prinsipnya Dilihat dari Segi Hukum Islam, Implementasinya pada Periode Negara Madinah dan Masa Kini, Jakarta: Kencana, 2004. 
Azizy, A. Qodri, Hukum Nasional Eklektisisme Hukum Islam \& Hukum Umum, Jakarta: Teraju, 2004.

Azra, Azyumardi, "Syariat Islam dalam Bingkai Nation State", dalam Komaruddin Hidayat dan Ahmad Gaus (eds), Islam Negara \& Civil Society Gerakan dan Pemikiran Islam Kontemporer, Jakarta: Paramadina, 2005.

Baltajî, Muhammad, Minhâj al-Tashrî al-Islâmî, Riyâd: t.p., 1977.

Dutton, Yasin, Asal Mula Hukum Islam Alquran, Muwatta', dan Praktik Madinah, Yogyakarta: Islamika, 2003.

Effendy, Bahtiar, Islam dan Negara Transformasi Pemikiran dan Praktik Politik Islam di Indonesia, Jakarta: Paramadina, 1998.

Feener, R. Michael, Muslim Legal Thought in Modern Indonesia, Cambridge: Cambridge University Press. 2007.

Gaffar, Afan, "Pembangunan Hukum dan Demokrasi", dalam M. Busyro Muqoddas dkk., Politik Pembangunan Hukum Nasional, Yogyakarta: UII, 1992.

Habermas, Jurgen, Knowledge and Human Interest, Boston: Beacon Press, t.t.

Hutabarat, Ramly, Kedudukan Hukum Islam Dalam Konstitusi-Konstitusi Indonesia dan Peranannya Dalam Pembinaan Hukum Nasional, Jakarta: Pusat Studi Hukum Tata Negara Fakultas Hukum Universitas Indonesia, 2005.

Ichwan, Moch Nur, "The Politics Of Shari'atization: Central Governmental And Regional Discourses Of Shari'a Implementation In Aceh", dalam R. Michel Feener dan Mark E. Cammack (Eds.), Islamic Law in Contemporary Indonesia: Ideas and Institutions, Cambridge, Massachusetts, Islamic Legal Studies Program, Harvard Law School, 2007.

Khallâf, 'Abd al-Wahhâb, al-Siyâsah al-Shar'iyyah, Qâhirah: Dâr al-Anșâr, 1977.

Lev, Daniel S., Hukum dan Politik di Indonesia: Keseimbangan dan Perubahan, Jakarta : LP3ES, 1990.

---------, Peradilan Agama Islam di Indonesia Suatu Studi Tentang Landasan Politik Lembaga-lembaga Hukum, Alih bahasa oleh Zaini Ahmad Noeh, Jakarta: Intermasa, 1986.

Lindsey, Tim, M.B. Hooker, Ross Clarke dan Jeremu Kingsley, "Shariá Revival in Aceh,", dalam Islamic Law in Contemporary Indonesia: Ideas and Institutions, diedit oleh R. Michael Feener and Mark
E. Commack, Cambridge, Massachusettes: Islamic Legal Studies Program, Harvard Law School, 2007.

M.B Hooker, Indonesian Syariah: Defining a National School of Islamic Law, Singapore: ISEAS, 2008.

Ma'arif, Ahmad Syafii, Islam dan Masalah Kenegaraan Studi Tentang Percaturan Dalam Konstituante, Jakarta: LP3ES, 1996.

Mahadi, Beberapa Tjatetan tentang Peradilan Agama, Medan: Fakultas Hukum U.S.U., 1969.

Mahendra, Yusril Ihza, Dinamika Tata Negara Indonesia: Kompilasi Aktual Masalah Konstitusi Dewan Perwakilan dan Sistem Kepartaian, Jakarta: Gema Insani Press, 1996.

Mahfud MD, Moh., Dasar dan Struktur Ketatanegaraan Indonesia, Yogyakarta: UII Press, 1993.

---------, Politik Hukum di Indonesia, Jakarta: LP3ES, 1998.

Mahmood, Tahir, Family Law Reform in the Muslim World, New Delhi: The India Law Institute, 1972.

Mas'ud, Muhammad Khalid, "Pencarian Landasan Normatif Syariah Para Ahli Hukum Islam" dalam Dinamika Kontemporer Dalam Masyarakat Islam, dihimpun oleh Dick van der Meij, diterjemahkan oleh Soemardi, Jakarta: INIS, 2003.

Mudzhar, M. Atho' dan Khairuddin, Hukum Keluarga di Dunia Islam Modern Studi Perbandingan dan Keberanjakan UU Modern dari Kitab-kitab Fikih, Jakarta: Ciputat Press, 2003.

Mudzhar, Mohammad Atho, Fatwa-Fatwa Majelis Ulama Indonesia: Sebuah Studi Tentang Pemikiran Hukum Islam di Indonesia, 1975 - 1988, Jakarta: INIS, 1993.

Muhammad, Rusjdi Ali, Revitalisasi Syariat Islam di Aceh Problem, Solusi dan Implementasi Menuju Pelaksanaan Hukum Islam di Nanggroe Aceh Darussalam, Jakarta: Logos dan Ar-Raniry Press, 2003.

N.J. Coulson, A History of Islamic Law, Edinburgh: Edinburgh University Press, 1991.

Noer, Deliar, Gerakan Modern Islam di Indonesia 19001942, Jakarta: LP3ES, 1996.

-.--.----., Partai Islam di Pentas Nasional Kisah dan Analisis Perkembangan Politik Indonesia 1945-1965, Bandung: Mizan, 2000.

Raharjo, Satjipto, Sosiologi Hukum, Perkembangan, Metode dan Pilihan Masalah, Surakarta: Muhammadiyah University Press, 2002. 
Rîs, al-, Muhammad Diyâ al-Dîn, Al-Nazaririyyât alSiyâsah al-Islâmiyyah, Qâhirah: Dâr al-Ma'ârif, 1967.

Salim, Arskal and Azyumardi Azra (eds), Shariá and Politics in Modern Indonesia, diedit oleh Arskal Salim dan Azyumardi Azra, Singapore: ISEAS, 2003.

Salim, Arskal, "Syariat Sampai Level Mana?", Harian Sumut Post, 12 April 2002.

Schacht, Joseph, An Introduction to Islamic Law, London: Oxford University Press, 1964.

Sjadzali, Munawir, Islam dan Tata Negara: Ajaran, Sejarah dan Pemikiran, Jakarta: UI Press, 1993.

Subekti, Law in Indonesia, Jakarta: Yayasan Proklamasi Center for Strategic and International Studies, 1982.

Syamsuddin, M. Din, Islam dan Politik Era Orde Baru, Jakarta: Logos, 2001.
Tâj, 'Abd al-Rahmân, al-Siyâsah al-Shar'iyyah wa alFiqh al-Islâmî, Mesir: Matba’ah Dâr al-Tảlîf, 1953.

Thalib, Sajuti, Receptio A Contrario Hubungan Hukum Adat dengan Hukum Islam, Jakarta: Bina Aksara, 1985.

Zein, Satria Effendi M., "Ijtihad Sepanjang Sejarah Hukum Islam: Memposisikan K.H. Ali Yafie," dalam Jamal D. Rahman (Ed.), Wacana Baru Fiqih Sosial 70 Tahun K.H. Ali Yafie, Bandung: Mizan, 1997.

"Munawir Sjadzali dan Reaktualisasi Hukum Islam di Indonesia," dalam Muhammad Wahyu Nafis (Ed.), Kontekstualisasi Ajaran Islam 70 Tahun Prof, Dr. H. Munawir Sjadzali, M.A., Jakarta: Paramadina, 1995. 